\title{
Resistance of Red Light District Communities in Responding Dolly Closure Policy in Surabaya City Indonesia
}

\author{
Pardamean Daulay \\ Postgraduate, Department of Sociology, Faculty of Social and Political Sciences, \\ Brawijaya University, Malang, INDONESIA \\ Department of Sociology, Faculty of Law, Social And Political Sciences, \\ Universitas Terbuka, INDONESIA
}

Sanggar Kanto

Department of Sociology, Faculty of Social and Political Sciences, Universitas Brawijaya, Malang, INDONESIA

Darsono Wisadirana

Department of Sociology, Faculty of Social and Political Sciences, Universitas Brawijaya, Malang, INDONESIA

Sholih Mu'adi

Department of Sociology, Faculty of Social and Political Sciences, Universitas Brawijaya, Malang, INDONESIA

\begin{abstract}
This paper discusses red light district community resistance after the closure of Dolly red light district which focused on the causes and forms of resistance carried out. This study used a qualitative approach with a case study in Dolly and Jarak as red light districts of Surabaya - Indonesia. The results of this study indicate economic mastery is a very important variable as a cause of resistance as well as a determinant of the resistance form made. Forms of resistance can be classified into three, namely; open resistance, symbolic resistance, and covert resistance. The form of covert resistance is far more dangerous because it can enter the wider community. The practice of covert prostitution has so far not been considered a resistance, but the strategy of surviving in the middle of the social space of the former Dolly red light district that is changing.
\end{abstract}

Key word: resistance, prostitution, Dolly, survival

\section{INTRODUCTION}

Prostitution is a hot topic discussed, because its existence raises pros and cons in society. On the one hand, prostitution has implications for the influence of morality, religion and other social values, but on the other hand prostitution is able to provide economic income for those involved in these activities (Sugiyono, et al., 2015), (Artosa, 2018). In some countries, prostitution is still considered a legitimate livelihood. According to the Intelligence Center (2009) of the 100 independent countries studied, it shows that most countries legalize prostitution. Nevertheless, there are still some countries whose governments do not legalize prostitution, such as in Indonesia, prostitution is prohibited and dissolved by the government. Data from the Ministry of Social Affairs of the Republic of Indonesia shows that until 2017, the government has succeeded in closing 118 red light districts in Indonesia and the remaining 59 red light district points will be closed no later than 2019 . 
One of the red light district of prostitution that has been closed by the government is the red light districtof Dolly in the city of Surabaya. The closure of Dolly red light district was carried out by referring to Regional Regulation Number 7 of 1999 concerning the prohibition on the use of buildings or places for prostitution. The plan to close this red light district has been since 2010, but the realization was carried out on June 18,2014. The aim is to save the fate of children in red light districts, raise the degree of humanity and the goodness of commercial sex workers (CSWs) and affected citizens by transferring professions (Budiraharso, 2014).

Every government policy is expected to be acceptable to all members of the community, but there are some policies that get resistance from some people when their interests and rights are not accommodated (Nugroho, 2014), (Hendriquez and Hartati, 2016). Like the closing process of Dolly red light district, even though it was closed 4 years ago, there are still groups that reject and carry out resistance till present. The form of resistance carried out by Dolly community is manifested in various ways, starting from the efforts of hearings with the Government - executive and legislative - to negotiate peacefully to launch pressure in the form of mass direction or demonstrations. In fact, there are some actors who fight through the practice of covert prostitution in the social spaces of Dolly and Jarak.

Sociologically, resistance is a movement or opposition that occurs because of dissatisfaction with something (Alisyahbana, 2005). According to Scott (2002), resistance is every act of members of a lower class of society with the intention of softening or rejecting the demands imposed on that class by the upper classes or to submit their own demands to these superior classes. Meanwhile, Siahaan (1996) argues that the poor do not do resistance because of the desire to create riots, but because of the limitations of alternative means that are able to voice their views on change.

So far, research related to the red light district closing policy in Indonesia has been carried out. For example Hermanto (2013) proved that the closure of Teleju red light district in 2009 through local regulations, made the act of prostitution increasingly difficult to eradicate because its existence became hidden so that prostitution was even more wild not only in the streets but also in the midst of people's lives. Janif, et al. (2014) found that the religious foundation built by the government and merely obeying the demands of a group of religious communities without deep consideration through social-philosophical discourse, especially the decision made with political tendency failed to eradicate the practice of prostitution in the city of Balikpapan. Whereas Amirah (2015) examines criminality policies about Dolly prostitution that are related to culture, social, and economic problems. Prostitution creates bad habits, such as getting drunk, drugs, gambling, and poses a big risk of HIV / AIDS transmission.

In contrast to the research of Hermanto (2013), Janif, et al (2014), Amirah (2015) who are more inclined to examine from a religious, economic-political, legal and criminal perspective, this study will examine the red light district community's resistance to Dolly closing policy in Surabaya. The focus of this research is to uncover the factors that led to the emergence of resistance and how are the forms of resistance carried out by the Dolly red light district community?

This research is important and urgent to do because so far the resistance of the poor to government policy has only been done by farmers in the countryside (Scott, 2002), (Siahaan, 1996), street vendors in urban areas (Alisjahbana, 2005). As far as the researchers known, there are no studies that specifically examine the resistance of the Dolly community both before and after the closure of red light district. In fact, even though it was officially closed by the government, some residents still resisted, for example in the form of covert prostitution in 
the former socialization area of Dolly. The difference was that prostitution was carried out openly, but now it is done in boarding houses and in a number of inns outside the red light district. If viewed from the side of prevention of HIV / AIDS, the phenomenon of covert prostitution is actually worrying and creates new unrest, because the CSWs infected with HIV / AIDS have the potential to spread to the community.

\section{RESEARCH METHODS}

This study uses a qualitative approach and a case study method, on the grounds that the Dolly red light district community's resistance to the policy of closing red light district is a social phenomenon that has its own characteristics and uniqueness. According to Denzim and Guba (Salim, 2001), case studies (case studies) are one of the methods of qualitative research that are focused on knowing the diversity and particularities of the object of study that are the target of the study. The use of case studies in this study is based on (1) conformity with exploratory research questions, (2) the chances of researchers being very small to control social events / phenomena that should not be examined, and (3) research is a contemporary social event / phenomenon (Yin, 2014).

The research location is Dolly and Jarak red light districts in Putat Jaya Village, Sawahan Subdistrict, Surabaya city -Indonesia. The choice of location is based on several considerations. First, the closure of the Dolly red light district had long been the agenda of several Surabaya mayors before, but the uncertainty of the red light districts closure continued. It was only during the leadership of Mayor Tri Rismahari that the closure of Dolly red light district was able and successfully carried out. Second, the community around Dolly red light district that had depended for decades on Dolly's existence do the resistance in an effort to preserve his life. Third, some CSWs and pimps who have received the severance pay give it back as a form of solidarity with the struggle of commercial sex workers, pimps and the surrounding community.

Research subjects and informants were determined based on Kanto's (2002) purposive sampling technique, namely those who understood resistance made by the Dolly red light district community, such as the Social Service, pimps, CSWs, street vendors, pedicab drivers, carpenters parking, management of the Surabaya Red light district Communication Forum, Independent Youth Community, and Red light district Work Front. Data collection was done through observation, interviews, and literature studies. All data collected was analyzed by the process of simplifying data into forms that are easier to read and interpret with several stages; reducing data by sorting, sorting data collected from interviews and observations, then grouping them into themes according to the research topic, and data interpreted systematically so that it is easy to read and understand (Moleong, 2006).

\section{Resistance of the Dolly Red light district Community \\ RESULTS AND DISCUSSION}

It is said that Dolly red light district, which was located in Putat Jaya area, was once a Chinese tomb area that was very quiet, dark, and seemed scary. It was only around 1966 that the area began to be transformed into residential settlements as a result of the invasion of migrants from various villages around East Java (Purnomo, 1983). The transfer of the function of the tomb has received permission from the local government, at that time the Mayor was $\mathrm{R}$ Soekotjo, who issued a policy that the Chinese tomb area was closed to new bodies and the old skeletons had to be transferred by his heirs to other regions. Since then, the arrival of people who want to get ex-grave land continues to increase (Purnawan, 2013). 
The transformation of settlements into prostitution occurred in 1967, which was marked by the emergence of a woman named Dolly Chavit who had also been known as a commercial sex workers and established a guesthouse (brothel) in the area. Dolly area began to reach its peak in 1968/1969, and the area has been packed with guesthouses with luxurious interior decoration (Purnomo, 1983).

In its heyday, Dolly was known as the largest prostitution area in Southeast Asia, beating Phat Pong in Bangkok, Thailand and Geylang in Singapore. Dolly red light district also transformed into the strength and back of life for the locals. Based on the documentation of Putat Jaya Village, there were 284 guest houses operating until Dolly closing in 2014. Of the 284 guest houses, there were 1,449 CSWs and 208 pimps who earned fortune in the prostitution business. They were all spread into 17 RTs (Rukun Tetangga-Neighbourhood Association) and 5 RWs (Rukun Warga-Hamlet) in Putat Jaya Village. It can be seen in table 1 for the complete information.

Table 1. Development of the number of commercial sex workers, pimps and guesthouses in Dolly red light district

\begin{tabular}{cccccccc}
\hline No & RW & CSWs & Pimps & \multicolumn{4}{c}{ Guesthouses } \\
\cline { 5 - 7 } & & & & 2011 & 2012 & 2013 & 2014 \\
\hline 1. & III & 555 & 41 & 81 & 76 & 69 & 69 \\
2. & VI & 104 & 16 & 23 & 21 & 21 & 21 \\
3. & X & 172 & 49 & 74 & 72 & 70 & 70 \\
4. & XI & 340 & 91 & 126 & 120 & 104 & 104 \\
5. & XII & 498 & 11 & 24 & 23 & 22 & 20 \\
Total & 1.449 & 208 & 114 & 312 & 286 & 284 & \\
\hline
\end{tabular}

Source: Monograph of Putat Jaya Village, 2016.

The Faidah Study (2014) shows that there are 37 types of businesses from nine business sectors that have developed in Dolly and Jarak red loght districts, namely: prostitution, security, cleanliness, providers of food consumption, health and supernatural services, transportation services, beauty services, credit services, and entertainment services. From some of these sectors, Hakim (2014) predicts the velocity of money that occurs in Dolly to reach 1-2 billion per night, where one homestay owner can earn income of 5 million to ten million per month.

Although prostitution in Dolly social space has a positive economic impact, it cannot be denied that it can also be a source of social, legal and health problems that are very disturbing to the community (Amirah, 2015). Based on these facts, the Surabaya City Government led by Mayor of Surabaya Tri Rismaharini and supported by the Governor of East Java and the Ministry of Social Affairs of the Republic of Indonesia closed the Dolly red light district.

The process of closing Dolly and Jarak red light districts, runs very tough and takes a long time. In fact, residents refused and resisted the policy of closing Dolly red light district. The results of this study indicate that there are several factors that cause the emergence of resistance red light district communities to Dolly closing policy, including; threatened economic rights, lack of socialization and negotiations, and discriminatory local regulations.

\section{Citizens' Economic Rights Threatened}

No one actually has a dream to become a sex worker. The women who became sex workers initially did not have the intention to become sex workers (Hudiono, 1998), (Suyanto, 2002), (Amirah, 2015). However, they were forced to carry out these jobs in order to maintain the family's survival. This is more or less the same as what was conveyed by informants who were prostitutes and pimps that they worked on for many years not a desire, but a compulsion. 
People living in the Dolly area also take the benefit from the Dolly prostitution crowd by creating jobs, such as making food stalls, drinks or even renting their home rooms for prostitution (Faidah, 2014).

According to Wisadirana and Hakim (2015), the presence of the prostitution business indeed opened up employment opportunities for local residents including Dolly and Jarak red light districts. Nova and Huda (2011) illustrate that a low-class pimp has only one guesthouse and ten CSWs can pocket IDR 80 - IDR. 90 million per month. If reduced by the operational costs of around IDR 40 million, they can pocket IDR 50 million per month. Whereas a CSWs' income is usually IDR 1,500,000 to IDR 3,500,000 per day. However, when Dolly red light district was closed, the CSWs' income dropped dramatically. Currently, most of them only get IDR 1.5 million per month. After the closure of Dolly, the economic turnover chain in this region has stopped, so many traders cannot trade, parkers must close, and washing workers lose their economic resources. Table 2 shows the actors affected by the economy from Dolly closure.

Table 2. Economic Affected Actors After the Dolly Red Light District Closure

\begin{tabular}{cllll}
\hline N0 & $\begin{array}{c}\text { Actor Business } \\
\text { Actor }\end{array}$ & \multicolumn{1}{c}{ Business Pattern } & $\begin{array}{c}\text { Income / Day } \\
\text { Before Closed }\end{array}$ & $\begin{array}{c}\text { Post-Closed } \\
\text { Income }\end{array}$ \\
\hline 1 & Pimps & $\begin{array}{l}\text { Profit sharing or } \\
\text { occupancy rent from } \\
\text { CSWs }\end{array}$ & $\begin{array}{l}\text { IDR 1000.000- } \\
2000.000\end{array}$ & Uncertain \\
& & $\begin{array}{l}\text { Income from } \\
\text { consumers (men) }\end{array}$ & $\begin{array}{l}\text { IDR } 500.000 \text { s.d } \\
1.000 .000\end{array}$ & IDR 300.000 \\
2 & CSWs & $\begin{array}{l}\text { Parking Services, } \\
\text { Laundry, Food Stalls }\end{array}$ & $\begin{array}{l}\text { IDR } 400.000 \text { s.d } \\
500.000\end{array}$ & IDR. 200.000 \\
3 & $\begin{array}{l}\text { Citizen of } \\
\text { RW/RT }\end{array}$ & $\begin{array}{l}\text { Supplier of goods for } \\
\text { Residents } \\
\text { around red light } \\
\text { district }\end{array}$ & $\begin{array}{l}\text { IDR } 1.000 .000 \text { s.d } \\
\text { CSW' needs }\end{array}$ & $\begin{array}{l}\text { There is no } \\
\text { income }\end{array}$ \\
\hline
\end{tabular}

Source: Field Data (processed), 2017.

Seeing these losses, it is natural if pimps and prostitutes reject the closure of red light district. The reasons for rejection are related to the economy problem. If Dolly red light district was closed, they were worried that they would not be able to continue their lives, while they had been dependent on prostitution for decades. The meaning of the policy of closing red light district for affected citizens is the same as eliminating employment and livelihood so that it is considered to violate the 1945 Constitution, article 27 paragraph (2), states "Every citizen has the right to work and livelihood that is appropriate for humanity". Article 28 D paragraph (2) is determined: Every person has the right to work and receive compensation and fair and proper treatment in work relations.

The word "right to" in the article means that the state (government) is obliged to provide employment with income according to human living standards. The question is that so far the creation of jobs is not comparable to demand so that citizens are forced to create their own jobs, but are easily closed by the government, without compensation and clarity of their fate after closure.

In addition, the closure of Jarak and Dolly red light districts was considered to violate human rights, especially rights relating to economic activity, the right to obtain employment, and the acquisition of wages. The United Nations General Declaration on Human Rights, in article 23 paragraph (1) states that "every person has the right to work, has the right to freely choose a job, has the right to fair labor conditions and is good and for protection against unemployment. 
In the International Covenant on Economc, Social and Cultural 1966, article 6 paragraph (1) determines "the participating countries of this agreement recognize the right to work which includes everyone for the opportunity to earn a living by doing work freely chosen or accepted and taking action - appropriate actions to protect this right ". Citizens have the right to live and the state must provide employment for every citizen. In other words, the closure of Dolly red light district resulted in the economic rights of citizens being threatened so that the government was seen as violating human rights.

\section{Discriminatory Regional Regulation}

Basically the Surabaya City government has the legitimacy to close Dolly, namely Perda Number 7 of 1999 concerning the prohibition on using buildings for prostitution activities. In reality, this regulation is considered to be still discriminatory because Dolly red light district was forced to close, but in other entertainment venues it was suspected that there was still the practice of prostitution and was left without strict supervision. In fact, prostitution in the city of Surabaya is still happening, even the practice of prostitution in these places has developed before Dolly was closed. However, the City Government by Civil service police Unit, the Police only raided the practice of prostitution that occurred in Dolly red light district, while the practice of prostitution in entertainment venues outside Dolly was never touched at all. Therefore residents protest against the government's indecision in addressing this injustice.

\section{Lack of Socialization and Negotiation}

The resistance of the Dolly red light district community began with the lack of socialization and negotiations from the Surabaya City Government regarding the closure policy of red light district. The results of the interview with one of the informants from the Surabaya City Social Service said that the socialization had been carried out to the Village Head, RT, RW and also residents around Jarak and Dolly. However, the statement was denied by the local community and stated that so far they had never received socialization, let alone involved to talk about handling the impact of closing Dolly and Jarak red light districts. The Surabaya city government only conducted socialization to certain parties who were considered to support the closure. Whereas, socialization to commercial sex workers, pimps and local residents who tried to oppose and refuse closure never existed, but the government quickly decided to close the township of Jarak Dolly.

The lack of communication relations between the Surabaya City Government and the elements in the Dolly red light district, such as commercial sex workers, pimps, and affected residents were considered as the trigger for the residents to carry out resistance. The Surabaya City Government, especially the Mayor of Surabaya, never sat together with CSWs, pimps and other affected residents to solve solutions after closing. Resistance is carried out because the government has never socialized the guarantee of job functions for commercial sex workers, pimps and affected residents. In other words, resistance is born from the behavior of people who are already comfortable with the conditions they are feeling so far, the community is worried that after the closure of red light districtit will change the structures that have been built.

\section{Forms of Resistance for the Dolly Red light district Community}

According to Scott (2000) the form of reisistence carried out by society in relation to social change is divided into two forms. The first is closed resistance (symbolic / ideological) such as gossip, slander, rejection of the categories imposed on society, and the withdrawal of respect for the authorities. Second, open resistance is an organized, systematic and principled form of resistance. The manifestation of this form of resistance is the use of violent methods, such as demonstrations and rebellions. 
The results of this study indicate that there are various kinds of open resistance actions carried out by the Dolly red light district community, including; making letters, holding demonstrations, putting up banners and pamphlets, rejecting the signboard "Putat Jaya Village is not a Red Light District Anymore".

\section{Make letter}

Citizens write a statement with the aim that the claim is not considered as a demand of one or two people, but the demands of many people collectively. In addition, the letter is expected to strengthen the position of the people who really want the closure of red light district. The letter also conveyed the wishes and demands that they could be facilitated to meet face to face and sit together to discuss the solutions to the economic life of the affected people after closing. Therefore, the letter was not only sent to the members of the Board, Mayor of Surabaya, but also to the President of the Republic of Indonesia Susilo Bambang Yudoyono.

Regarding human rights violations, Dolly residents have specifically sent a letter to the National Human Rights Commission asking the commissioner of the National Commission on Human Rights to come and see firsthand the conditions experienced by affected people. Responding to the letter from the residents of Dolly and Jarak, the National Human Rights Commission actually stated that the problem of Dolly closure had to be an agreement on the solutions and responsibilities of the government towards the local residents. They have lived in prostitution areas for decades and most of them have made it as an economic resource. Meanwhile, the Dolly red light district community has fulfilled its obligations to the State, in the form of paying taxes. That way, the community has carried out its obligations to the government, which is then managed by the government to be distributed again to the community.

\section{Conduct Demonstrations}

Demonstrations are options taken by residents affected by the closure of Dolly red light district to voice opinions, support, and criticism. Demonstration is an action to convey rejection, criticism, suggestions, impartiality and disagreement through various means and media with rules that have been established both in writing and unwritten as the accumulation of shared votes without being influenced by personal or group interests. Demonstrations are a form of expression of opinion which is the right of every citizen regulated in the Law. Demonstration is explained in Article 1 paragraph 3 of Act Number 9 of 1998 concerning Freedom of Delivering Public Opinion, namely demonstration is activity carried out by one or more people, to express thoughts in a verbal, written and demonstrative manner in public, with the principle of a balance between rights and obligations, deliberation of consensus, legal certainty and justice, proportionality, and the principle of benefits.

One of the actions carried out by affected residents with CSWs, pimps, and homestead owners in rejecting the policy of closing red light district was by holding a demonstration. The residents took the first demonstration to the Putat Jaya Urban Village office and Sawahan District office. The demonstration at that time was carried out as a first step in influencing the government's decision to close Jarak and Dolly, where affected residents requested that the government cancel the policy.

Furthermore, demonstration was held at the Surabaya Mayor's office and the Regional House of Representatives office because the demands that were originally sent by mail never received a response. The demonstration this time was attended by dozens of CSWs, homestead owners and affected residents living around Dolly red light district, and supported by a number of elements in the name of civil society, such as Independent Youth Community, Red light district 
Work Front and People's Movement United. All elements of the community felt anxious about the plan to close the red light district. Especially, it is impressed that the residents began to be slowly removed. The affected people who have been relying on the prostitution business are desperately trying to maintain Dolly red light ditrict. The demonstration was a warning to the Government, if it remained insistent on closing the red light district, residents were ready for war until the last drop of blood. Affected residents requested that the closure of red light district be postponed until 2018 as the government prepares the handling and transfer of professions for affected residents.

\section{Installing Banners and Pamphlets}

The next way to fight is through the installation of banners and pamphlets. Along Putat Jaya road, residents put up a variety of banners, including "Ojo Ngrusuhi Dolly (Don't Disturb Dolly)", "Fair Human Rights Violations", "Give Us Worthy Life", "Don't Ease Us", and "Close Dolly or Revolution". One banner even read "Soekarwo and Risma Failed to make the People Prosperous".

In each demonstration and demonstration, affected residents always carry writings that contain rejection of the closing policy of Jarak and Dolly red light districts. The installation of banners and pamphlets is proof that the affected residents refused to close Jarak and Dolly red light districts.

\section{Refusing the Signboard "Putat Jaya Village is not a Red Light District Anymore"}

Tensions that continue to occur in the Dolly and Jarak areas had eased because residents who refused closure began to reduce their resistance activities. The fading of this tension is not because residents have agreed to the closing policy, but as respect for Muslim brothers who are fasting. Indeed, it has become a habit for residents around Dolly and Jarak, if the fasting month of Ramadan all activities related to the sex business in red light district are stopped (Bachtiar and Purnomo, 2007). The closing of Dolly-Jarak red light districts were only temporarily, because after Eid the prostitutes and the surrounding community had agreed that the routine in the red light district would be opened again.

However, ahead of the Eid-ul-Fitr festivities, the tension continues. This was due to the firm attitude of the Surabaya City Government who wanted to close Dolly and Jarak red light districts as a prostitution area, which led to clashes between the officers of the Surabaya Civil Service Police Unit and groups of citizens who refused to close Dolly and Jarak red light districts. Clashes between residents and the Civil Service Police Unit began with a plan to install a placard that read "Putat Jaya Village is not a Red Light District Anymore".

The refusal action began when several residents confronted the authorities who would guard the installation of the signboard. Residents collected several tires and laid them in the middle of the road. Shortly afterwards, the Head of the Civil Service Police Unit came to the crowd and banned the burning of tires around the area. The statement apparently sparked the emotions of the masses so they began burning tires, taking placards that had not been installed and burned. As a result, physical clashes between police officers, Surabaya Civil Service Police Unit, and local residents were inevitable. The crowd became increasingly angry and resisted when Civil Service Police Unit officers tried to extinguish the fire. The situation became increasingly heated after the police fired tear gas to destabilize the masses.

The report of residents' rejection of the installation of signposts followed by anarchist action caused the police to quickly deploy to the location. They immediately hunted down residents and FPL activists who indeed from the beginning of the declaration of the closure of Dolly and 
Jarak red light district became the target of the police. One by one those who were considered provocateurs were arrested by the police. Residents and Red light district Work Front activists who refused to close were arrested with conditions full of blood on his body. As told by Mbah Yit, one of the victims who was hit by the police. At that moment his head was beaten until it bled as seen in (figure 1), then was arrested and taken to the police station. After being questioned, Mbah Yit was found not guilty and released.

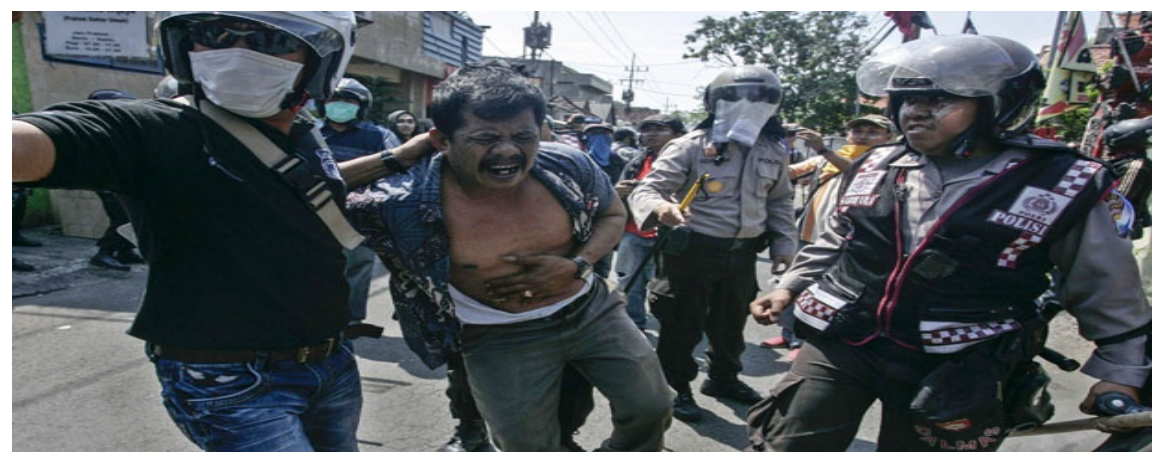

Figure 1. One of the informants (mbah Yit) who was beaten by the police. Allegedly, he was a provocateur of the demonstration refused the installation of a sign that read "Putat Jaya Village is not a Red Light District Anymore".

Meanwhile, mobile police units forces conducted sweepings into alleys which had been suspected of being pockets of citizen power and Red light district Work Front activists who had initially refused to have Dolly-Jarak red light district closed. The Red light district Work Front post located in Dolly red light districtwas not escaped by the officers. Although the post was locked, the police insisted that the door be opened. Two Red light district Work Front activists inside the post were immediately forcibly arrested, namely Saputro, who was usually called Pokemon and Suyitno (parking owner). Saputro is the Chair of Independent Youth Community and Suyitno is the Red light district Work Front Coordinator who is very strict in refusing Dolly closure. Finally, the police determined 11 suspected riots in Dolly and Jarak. Some suspects were charged with incitement and against officers. After the arrest of residents and activists of Independent Youth Community and Red light district Work Front, then it reduced the courage of citizens to openly resist.

In maintaining the existence of Dolly, which is said to be the largest in Southeast Asia, affected residents not only use open resistance through violent means, but they also use closed or hidden resistance. The results of this study found hidden resistance through religious and cultural symbols, such as "istighosah" activities, tumpengan, flag ceremonies, slaughtering of white buffalo, and reproducing the practice of covert prostitution.

\section{Istighosah and Tumpengan}

According to affected residents, the declaration of closure of red light district carried out at the Islamic Center on June 18, 2014 did not have legal force because in the statutory regulations it was never mentioned that the declaration had legal force. The declaration was only a political policy so CSWs, pimps and affected residents could hold a similar declaration by refusing to close the red light district of prostitution. The declaration of the rejection of the citizens was carried out by holding "tumpengan" and "istighosah" to counter the declaration of closing Dolly and Jarak red light districts held by the Surabaya city government.

Presetiyo (2018) states that tumpeng 'is an acronym for the phrase 'yen meTu kudu meMPENG ', "which means "when exiting must be truly zealous". That is, humans when born must live their lives in the path of God, confident, focused, not easy to despair.Therefore, the cone has a 
cone shape and its side dishes are served, cone shapes represent the concept of divinity with something big, tall and at the top, while the side dishes are prepared as many as 7 kinds. In Javaneese language, seven is pitu, which means pitulungan (help). Referring to the opinion of Presetiyo (2018), the purpose of the residents to do a tumpengan is a prayer request to God so that Dolly and Jarak will not be closed. The istighosah and cutting cone is done in front of the existing guesthouse in Dolly red light district, commercial sex workers, pimps and affected residents attended the event by inviting a Kyai Kandeng from Kediri. The atmosphere of istighosah and tumpengan activities takes place solemnly as seen in Figure 2.

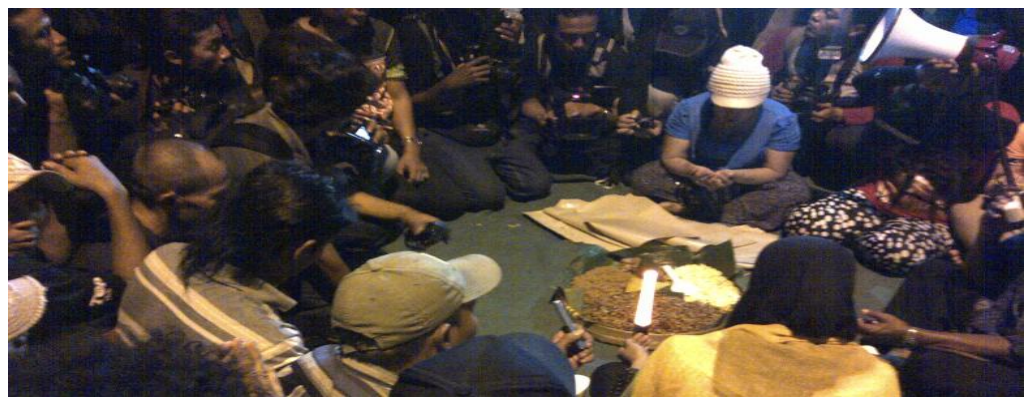

Figure 2. Residents reject the closure of Dolly red light district by performing Istighosah and tumpengan led by a Kiyai (religious figure).

There are several meanings to be conveyed by the affected citizens behind this istighosah and tumpengan program, namely; First, the istighosah and cutting cone activities are part of the people's declaration rejecting Dolly and Jarak's closure. This tumpeng also contains prayers, not only implies that the demands are not true from the government, but also shows the general public that the residents of Jarak and Dolly, not fools who are easily deceived. Second, delegitimizing stigma and public perceptions of people who are in red light district as people who are evil, mischievous and the source of all social problems. Citizens say that the people who live in Dolly red light district are the same as other communities, have religion and worship. Third, it would like to show the general public that the representatives who read the declaration of the closure of Dolly red light district were not affected residents. If the government takes the name of Dolly and Jarak residents, then it proves there is a public lie carried out by the government.

\section{Flag ceremony}

During this time the flag ceremony activities have the meaning to safeguard the values of national unity and integrity, foster the spirit of nationalism, love the country and increase the sense of spirit of initiative or sense of togetherness. However, this research shows a unique and unusual scene, where commercial sex workers and pimps with affected residents in the red light district of Dolly hold a flag ceremony. The ceremony is held simply as a symbol and affirmation of the CSWs statement rejects the closure of red light district.

The participants of the ceremony were CSWs, pimps, local residents, and activists of Independent of Youth Community and Red light district Work Front. In figure 3, it can be seen that the one who became the ceremonial leader was the Independent of Youth Community activist who doubled as a corelator. Some CSWs use tight and sexy clothes, while and to hide their identities, they cover their faces using masks. 


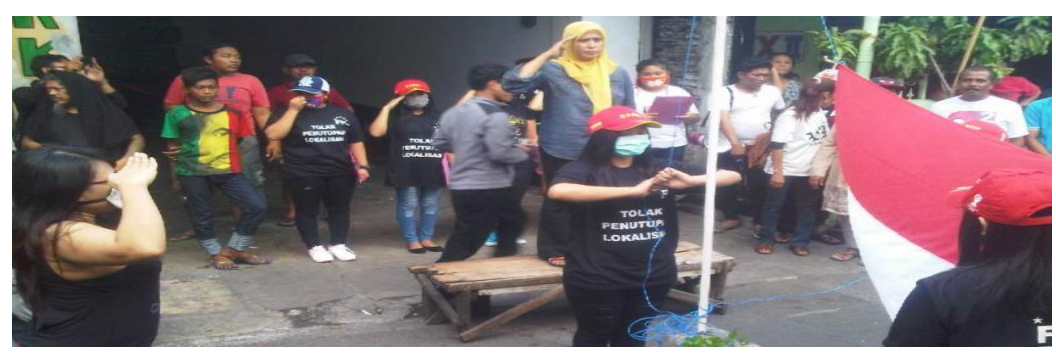

Figure 3. Implementation of the flag ceremony followed by commercial sex workers, Pimps and residents around Dolly red light district

The flag ceremony carried out by dozens of sex workers has the aim that the government and all people know that CSWs are Indonesian citizens who love the country, always maintaining the values of national unity and integrity, fostering a spirit of nationalism, and enhancing a sense of togetherness. For this reason, they asked that their fate and life be considered and heard by their aspirations.

\section{Slaughtering White Buffalo as a Dolly-Jarak's Tumbal}

The next symbolic action is to parade the white buffalo around Dolly red light district and end with the slaughter of the animal as tumbal. In the Indonesian language dictionary, tumbal is defined as something that is used to reject reinforcements or offerings to get something better. The procession was started from the Red light district Work Front Post, then entered the red light district alleys in the area. When parading the buffalo, there is a paper card with 'Tumbal of Dolly-Jarak' on it. In addition, the cardboard was also written the name of the Governor of East Java, Soekarwo, Mayor of Surabaya, Tri Rismaharini and Head of the Surabaya Social Service, Supomo. More can be seen in Figure 4.

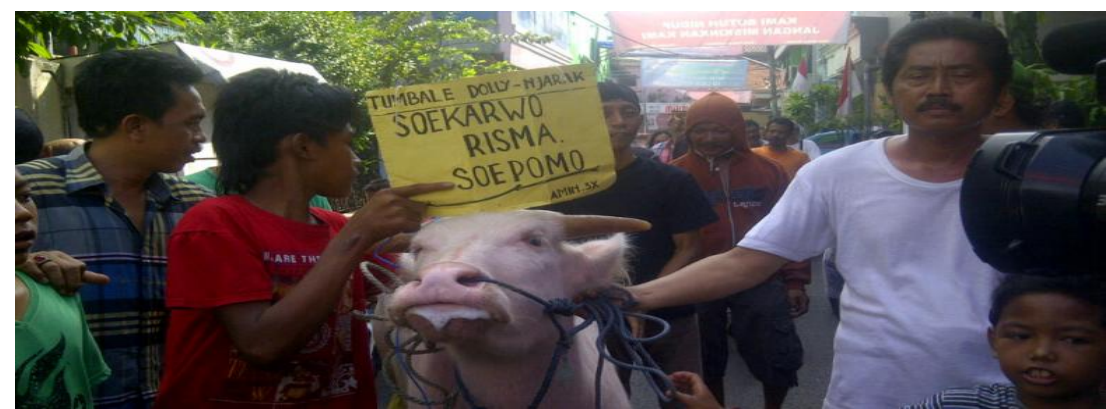

Figure 4. Procession of White Buffalo around Dolly Red Light District as a tumbal of Dolly citizens

According to one informant the price of one white buffalo is IDR 100 million. Funds for buying white buffalo are obtained jointly from pimps, homestead owners and residents around Dolly and Jarak. However, in order to refuse the closure of Dolly red light district, residents did not mind buying that price. This shows that if citizens really want the existence of Dolly red light district to continue in Surabaya.

The slaughter of white buffalo as a victim of Dolly residents has its own meaning as a prayer and hope that the red light district will continue to operate and can support the surrounding community. Nurcholis (2014) states that in the Javanese tradition, white buffaloes have symbolic meanings, among others; bring blessings and salvation from the Almighty, have the sensitivity to drive away evil spirits or bad intentions, and buffaloes are interpreted as stupid animals as in the Javanese idiom "bodho plonga plongo koyo kebo" (stupid idiots look like buffalo). In addition, buffaloes are also symbolized as small people, especially for farmers. As is known that Indonesia is an agricultural country that is synonymous with agricultural life, not 
separated from the buffalo animal. That is, the country will be strong if the small people are also strong. Buffalo may be a symbol of slowness, obesity and ignorance. Mawardi (2011) explains the story of buffalo and apes containing moral teachings, symbolic agrarian and work ethic. Buffalo can also be transformed as a symbolic power, semiotic and semantic when placed in a political context.

\section{Covert Prostitution Practice}

The Surabaya city government has been working hard to make changes to the new social space in the former red light district of Dolly and Jarak, but the strong habitus as a prostitute and pimps have resulted in them returning to the old profession. This group wants to maintain the existence of red light district by carrying out resistance to seize access that still exists. According to Bourdieu (2015) the strategy used by individuals depends on the amount of capital owned and its position in the social space. If they are in a dominant position, the strategy carried out is directed at preserving and maintaining existing capital, while those in subordinated or dominated positions try to seize and change their capital distribution so that the social level increases.

The data findings of this study support the opinion of Boerjoeu, where the group that resisted and still wanted to reproduce the prostitution business was a group that had enjoyed the sweetness of the golden age of red light district. They believe that red light district is indeed something that can be eradicated and even eliminated, but prostitution is not an easy thing to eliminate as long as demand continues to arrive (Hull et, all, 1997), (Suud, 2015). The Consumers as the customer of their business will not ever been exhausted so that the opportunity to re-open a prostitution business in Dolly ex-red light district social space is still promising.This is very relevant to what Syam (2010) said that prostitution is indeed a social phenomenon that knows no place and atmosphere. In fact, prostitution is part of a social institution that will remain sustainable and even develop as long as it is needed.

Dolly closing policy, as of yet, did not reflect what was envisaged as Regional Regulation No. 7 of 1999 used by the Mayor of Surabaya as the basis for closing the red lisght district of JarakDolly. The regulation regulates the prohibition on using buildings or places for immoral acts in the city of Surabaya. In other words, the red light district of Dolly has turned into an ordinary residential place, but efforts to continue the prostitution business activities as before are still ongoing. The social network between pimps and pre-existing CSWs is maintained and they also agree to continue what is their routine before the closure (Oktaviari, 2017). That is, those who reject closure have realized that Regional Regulation No. 7 of 1999, prohibits the use of the guesthouse and other places to carry out sex services, including in the former Dolly red light district area. However, as individuals who have rational actions and resources as Giddens (2010) mentioned, they have ideas and thoughts that there are still other places that can be used for sex services for customers, such as in hotels, boarding houses, and so.

This community group that is resisting is less interested in undergoing other professions such as entrepreneurship by relying on training facilities provided by the government. Various trainings or all kinds of forms of handling the impact of the closure of the red light district provided by the government. It is seemingly always responded with indifference and lazy actions. This was done because of their instant mindset and mindset, where they were accustomed to light work but got easy, fast, large amounts of results like they had before the closing of Dolly red light district. They have received this kind of mindset since childhood so that it has become a habitus that is difficult to stop. 
This strong prostitution habitus has implications for the efforts they have made by choosing to stay on track before the closure of red light district, but it is tricked by forming covert prostitution practices. Some men who work as pimps on the roadside offer sex workers to every man who passes in front of them. While greeting with polite language, they offered prostitutes with invitation words such as "Come on, bro, the children are there, guaranteed to be smooth and original ex-Dolly." Although only showing photos of women on smartphones, they are sure customers will not be disappointed with the service.

Not only in Dolly, in the former Jarak red light districts, there were still many pimps offering sex workers. However, it is not too flashy in this place because pimps mingle with people who are enjoying coffee in the stalls around it. In fact, there are also pimps who pretend to be pedicab drivers. While sitting on a pedicab as if they were looking for passengers, but they keep an eye on anyone who passes, then greet by offering services "accompanying to CSWs who is ready to use". The practice of sex transactions in coffee shops and pedicab drivers is justified by the coffee shop owners around the Jarak road as follows:

".... now using the booking system, the girl is not at the guesthouse. If you want a girl that suits you, her pimps tell you through the photos in BlackBerry that they carry,". For one booking, the rates vary depending on the chosen girl. "There are IDR 300 thousand, there are also IDR 450 thousand. Depending on the class of girls you choose." If you are interested, I can find it with the person (pimp). That was one of the people hanging out here (Interview, February 15, 2017).

Based on the interview, it is proved that prostitution actually existed in the Dolly and Jarak red light district, which was once dubbed as the largest red light district in Southeast Asia, had not really died. Only the transaction method is changed by the actors involved to anticipate all regulations relating to the policy of closing red light district and avoiding the raid on the Civil Service Police Unit. The findings of this data support the results of Alexander (1998) 's research which shows that policies to localize prostitution in embroidery houses are still needed because the prohibition on prostitution cannot reduce prostitution practices, but can lead to street prostitution which is very difficult to detect and also difficult to monitor the spread of diseases sexual HIV / AIDS. Meanwhile, Wisadirana and Hakim (2015), showed that the policy of closing red light district had not been fully successful, this was not only caused by government mistakes, but also collective doubts of the wider community, religious leaders, community leaders, and affected communities who seemed unwilling move from the comfort zone.

The practice of sex transactions that are currently developing in the former Dolly and Jarak red lighr districts, it turns out that it does not always run smoothly, but often gets obstacles from the Civil Service Police Unit officers who always carry out raids. Thus, reproducing the practice of prostitution covertly in Dolly red light district is basically unsafe and vulnerable to a number of risks. However, the role of each actor has actually prepared a number of strategies to overcome these risks. It can be said that when they have to deal with the policing operation from the Civil Service Police Unit, they volunteered to be arrested by the police, but they would do tactics to deal with it, such as they cooperated with village officials about when the operation was carried out. The interesting thing is that the Civil Service Police Unit officials warned that the community should not carry out prostitution activities in Dolly red light district, they do not respond with resistance in the form of violent expressions. They seemed obedient and heeded a number of "rules of the game". However, after the warning and curbing operation took place, they again passed the "rules of the game". These are forms of care that are expressed shyly which can be classified in the form of non-violent receipts (Scott, 2000). 


\section{CONCLUSION}

Dolly red light district community resistance is related to economic problems. Economically, resistance is born from the behavior of people who are already comfortable with the conditions they are feeling so far. The community is worried that after the closure of red light district it will change the structures that have been built. The resistance of Dolly residents received support from NGOs as a knot of the civil society movement, such as Surabaya Red Light Districts Communication Forum, Red light district Work Front, and Independent Youth Community. The red light district community carried out resistance was also caused because the commitment of the Surabaya city government in removing prostitution was considered not fully serious according to Regional Regulation No. 7 of 1999. This was due to the wellestablished red light district of Dolly and Jarak, but on the other side there were many places / buildings that underwent massage parlors, salons, and karaoke places that were still open. The forms of public rejection have not been structured and patterned clearly so that they have not become a social movement that can change government policies. This form of resistance is based on a number of social actions in the form of timid expressions of resistance or nonviolent forms of resistance. On the one hand, they realize that the resistance done is against the rules, but on the other hand they have to maintain their lives and the survival of their families.

\section{References}

Alexander, P. (1998). Sex Work and Health: A Question of Safety in the Workplace, Journal Jamwa, 53(2).

Alisjahbana, (2005). Perlawanan Pedagang Kaki Lima Kota Surabaya Dalam Menghadapi Kebijakan Pemerintah Kota (Suatu studi tentang staregi PKL Kota Surabaya dalamMempertahankan Hidup), Disertasi, Unair,

Amirah, A. (2015). Cultural, Social, and Economic Perspectives in Making a Criminal Policy (Dolly Prostitution), The Journal of Macro Trends in Social Sciences, 1(1), 45-53.

Artosa, Odam Asdi. 2018. 'Pekerja Migran dan Ekonomi Informal Ilegal (Prostitusi) di Wilayah Pasar Kembang,Yogyakarta'. Jurnal Pemikiran Sosiologi 5(1), 21-36

Bachtiar, Reno dan Purnomo, Edy, (2007). Bisnis Prostitusi: Profesi yang Menguntungkan, Yogyakarta, Pinus.

Bernard, M. A. (1993). Violence and Vulnerability: Condition of work for street - working prostitution, Sociology of Health and Illness. Journal University of Glasgow, 15(5), 683-705.

Bourdieu, Piere. 2015. Arena Produksi Kultural; Sebuah Kajian Sosiologi Budaya. Bantul: Kreasi Wacana.

Budiraharso., Sandhy., \& Aditya, (2014). Risma Perempuan Hebat dan Fonomenal, Yogyakarta, Sinar Kejora.

Choirul, (2017) Prostitusi Gang Dolly Surabaya Tamat, PSK Terselubung tetap Semarak, diambil dari Kamis, 12 Oktober 2017 11:45 WIB

Faidah, Mutimmatul (2014).Pusaran Ekonomi Di balik Bisnis Prostitusi Di Lokalisasi Dolly-Jarak Surabaya Lentera. Jurnal Studi Perempuan, 10(1).

Giddens, Anthony. (2010). Teori Strkturasi: Dasar-dasar Pembentukan Struktur Sosial Masyarakat, terjemahan Maufur \& Daryanto. Yogyakarta: Pustaka Pelajar.

Hendriquez,Ace,E., dan Hartati, Lisa,EP, (2016). Pemenuhan Hak-Hak Pekerja Sesual di Indonesia, Proceeding The 1st International Conference on Social Sciences and Humanities (ICSSH), LIPI, 2016, hal. 1551 - 1558

Hermanto, Bambang (2013). Penanganan Patologi Sosial Dalam Perspektif Sosiologi Hukum Islam (Studi Kasus Penutupan Lokalisasi Teleju Oleh Pemko Pekan Baru, https://lppuinsuska.wordpress.com/2012/02/07/36/ diambil tanggl, 15 April 2015.

Hudiono, Esti Susanti. Pemberdayaan Kaum Perempuan dan Pelacuran dalam Kumpulan makalah. Seiminar Sehari Tentang Penutupan Lokalisasi Pelacuarn.1998. Jakarta: YTKI.

Hull, dkk. 1997. Pelacuran di Indonesia, Sejarah dan Perkembangannya, Jakarta, Sinar Harapan.

Janif Z, Nur, F., Enos, P. (2014) Analisis Kebijakan Penutupan Lokalisasi Prostitusi Km 17 Di Balikpapan, eJournal Administrative Reform, 2014, 2 (1), 1199-1212 ISSN 2338-7637, diakses dari ar.mian.fisip-unmul.ac.id, tanggal 15 April 2015. 
Daulay, P., Kanto, S., Wisadirana, D., \& Mu'adi, S. (2018). Resistance of Red Light District Communities in Responding Dolly Closure Policy in Surabaya City Indonesia. Advances in Social Sciences Research Journal, 5(12) 296-310.

Kanto, Sanggar (2012), Sampling, Validitas dan Reabilitas dalam Penelitian Kulitatif, dalam Bungin, Burhan, Analisis Data Penelitian Kualitatif. Pemahaman Filosofis dan Metodologis Ke Arah Penggunaan Model Aplikasi, Jakarta, Rajawali Press.

Mawardi, Bandung (2011), Kerbau dalam Peradaban Jawa, www.jatengpos.com, diambil 4 September 2018.

Moleong, Lexy J. (2006). Metode Penelitian Kualitatif, Remaja Rosdakarya, Bandung.

Nova, S., \& Huda, N. (2011). Permata dalam lumpur Merangkul anak - anak dari lokalisasi Dolly, Jakarta, PT Elex media komputindo.

Nugroho, Riant, (2012). Sosial Policy for the Developing Countries, Pustaka Pelajar, Yogyakarta.

Nurcholis (2014). Asal Usul Kerbau Bule Kiai Slamet, dikutip dari https://daerah.sindonews.com, tanggal 04 September 2018

Oktavaria, N.S dan Handoyo, P (2017),Jaringan Sosial Mucikari Pasca Penutupan Lokalisasi Dolly Surabaya, Jurnal Paradigma. Volume 05 Nomor 02 Tahun 2017, http://jurnalmahasiswa.unesa.ac.id/index.php/paradigma/index

Presetiyo, Ari, (2018). Makna Filosofis Nasi Tumpeng. Diambil dari https://www.sahabatnestle.co.id/content/resep/makna-filosofis-nasi-tumpeng.html

Salaim, Agus, (2001). Teori dan paradigma Penelitian Sosial dari Denzin Guba dan Penerapannya, Tiara Wacana, Yogyakarta.

Scott, James, (2002) Perlawanan Kaum Tani, Jakarta: Yaysan Obor Indonesia.

Scott, James. 2000. Senjatanya Orang-orang yang Kalah; Bentuk-Bentuk Resistensi Sehari-hari Kaum Tani. Jakarta : Yayasan Obor Indonesi

Syam, Nur (2010). Agama Pelacur: Dramaturgi Transendental, Yogyakarta, LkiS.

Sugiyono, Inayah, N., Biati, L., Andriani, Z.Z.D., Nasrullah, M.A., 2015. “Dampak Sosial Penutupan Lokalisasi di Kabupaten Banyuwangi: Studi Kasus Tentang Faktor Penyebab Mantan PSK Kembali Bekerja Di Lokalisasi Turian Purwoharjo Banyuwangi". Jurnal Hukum Islam, Ekonomi dan BisnisVol. 1, No.1, Hlm. 1-16.

Suud, Muhammad. (2015). Appropriate Policy on Prostitution in Indonesia: A Strategy to Minimize Social Impacts in Society. Public Policy and Administration Research, Vol.5, No.10, 2015

Suyanto, Bagong, (2012). Anak yang Dilacurkan dari Perspektif Teori Kritis, Disertasi, Universitas Airlangga, Surabaya.

Wisadirana dan Hakim. (2015), Perlawanan Sosial Masyarakat Lokalisasi Atas Kebijakan Pemerintah, Malang, Intelegensia Media

Yin, Robert. (1996). Studi Kasus: Desain dan Metode Manajemen. Radja Grafindo Persada. Jakarta. 